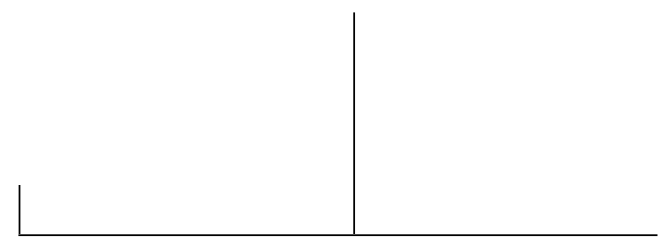

Rev. Latinoam. Psicopat. Fund., São Paulo, v. 15, n. 3, p. 668-682, setembro 2012 (Suplemento)

\title{
The Body in Anorexia and Bulimia*
}

Maria Helena Fernandes

The psychoanalytic clinic for anorexia and bulimia puts us into immediate contact with the question of the body, as well as with aspects typical of adolescence. These aspects especially include difficulties in early relationships with the mother regarding the management of the drives, and relationships with primary identification. Consequently, we are dealing with ideals, differentiation, autonomy, time and death. Here hypotheses that were drawn up on the basis of metapsychology are discussed, with the objective of contributing to a broader understanding of the construction of the bodily image. This process includes the perception, representation and internal experience of the patients' own bodies. The impasses experienced in the analytic situation also indicate particularities in managing the transference in these cases.

Key words: Anorexia/bulimia, bodily image, metapsychology, managing the transference

* The ideas presented here are a part of what was developed and discussed at length in my book Transtornos Alimentares: anorexia e bulimia (São Paulo: Casa do Psicólogo, 2006). 
Michelle is 14 years old and is in hospital due to her deteriorating physical condition. She weighs only 32 kilos (70 pounds), and yet refuses to eat; she hasn't had her period menstruated for several months. A therapeutic team was organized to treat her, consisting of a psychiatrist, a psychoanalyst (this author), a general medical clinician and a nutritionist. Michelle's hospital room is always full of food. However, the delicious treats, fresh fruit and fine chocolates seemed to be met with disdain in her faraway gaze. When I see her for the first time, still in the hospital, she's being fed through a gastric tube inserted into her side. I recommend the family to remove any kind of food from the room. Three weeks later she's released from the hospital and continues her treatment at my private office.

Another patient, Ligia, came to analysis feeling very depressed and was taking anti-depressive medication. She was eating and vomiting as many as seven or eight times a day. Scrawny looking, she talked about her great fear of getting fat and ugly. In spite of her physical condition, the attractive features of this young woman lady caught my attention. She was dedicating a great deal of time every day to physical exercises and said that they made her feel "relieved." After finishing college her episodes of bulimia soon thwarted her hopes of going into graduate school. She very reticently began her analysis and said that she had already been in therapy twice before, but, she said, "Neither experience did me any good."

Renata also considers herself depressed. At our first interview she complained of feeling bashful, and this had made it very difficult for her to relate to others "the way she used to." When trying to understand the "continental divide" that let her set down anchor, with one side before and the other later, I could see that Renata was 
talking about the fact that she had broken up with her boyfriend and that she felt responsible for the separation. She made this decision after an accident that left her bed-ridden for several months. But I became intrigued when she told me that, during the first months after the end of the affair, she felt fine and was at peace with her decision. Only with time did she begin to "torture herself" and become overly concerned with her physical condition and her being overweight, often feeling "ugly, fat and unattractive."

What I intend to bring up for discussion here is what I was able to learn from these young women, as well as from so many others, about their suffering, their obstinacy, their utter helplessness and their intense will to live. It was this learning process that enabled me to establish the working hypotheses that I will present briefly in this text. The diversity of psychopathologies found in psychoanalytic clinical work with anorexia and bulimia inevitably brings up the question of the body and the specific aspect of processes during adolescence, especially in girls. These specific pathologies seem to indicate difficulties in early relationships with the mother regarding the management of the drives and their connection with primary identification. This consequently also has to do with ideals, differentiation, autonomy, time and death.

In my most recent book I investigated and metapsychologically articulated these many different aspects and their clinical resonances. But, of course, it would be impossible to discuss all of these aspects in the limited space of the present article. We will thus focus basically on the question of the perception of the body in anorexia and bulimia, and point out the difficulties in managing the transference in such cases.

\section{A Body in the Negative}

The question of the body leads to the problem of the distortion of the bodily image, ranging from difficulties in perceiving physical stimuli coming from inside and outside, to distortions of the bodily image of truly delirious proportions, of the type described by Bruch $(1973)^{1}$. There are also difficulties in discriminating between the inside and the outside. Everything happens as if the patient's own body was failing to exercise one of its central functions, which is to set up the boundaries between inside and outside and thus exercise the function of the body

1. See the book Eating disorders: obesity, anorexia nervosa and the person within, by Hilde Bruch (Harper Torchbooks, 1973). 


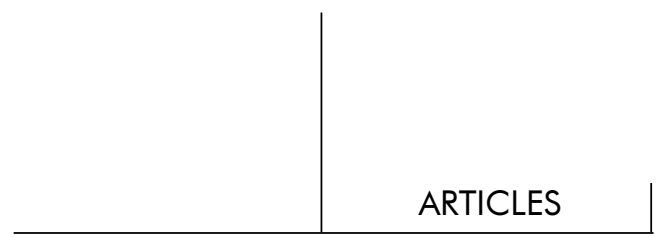

as a borderline between the ego and the other. This difficulty in discriminating between inside and outside shows how precarious the boundaries between subject and object are for these patients, evidenced by their lack of autonomy and their difficulty in differentiating themselves from the figure of the mother.

Many writers, including André Green, correctly suggest that anorexia and bulimia can be classified in the category we now refer to as borderline cases, and might even be more literally described as border cases. I believe that the most interesting aspect of this nosographic category is precisely in the notion of boundary or, more precisely, in the notion of a border, which is what these pathologies seem to constantly evoke. They refer to boundaries between inside and out, between the ego and the other, between reality and fantasy, and between representation and the unrepresentable. These pathologies also have to do with the differences between nosographic categories, such as the borders that distinguish psychosis from melancholia and hypochondria, for example.

Shortly after beginning her analysis, Michelle was still very thin. But she said she could not understand why everyone kept looking at her when she came into a room. On sunny days she would sometimes come to her sessions very warmly dressed, wearing heavy stockings and a wool cap. Although we know that this type of absence of perception of outside stimuli, including cold and heat, can be associated with malnutrition, one cannot fail to notice that such patients also have faulty perception of internal stimuli, such as failures to perceive hunger and, apparently, the ensuing gastric pains. The same thing happens with the effects of physical hyperactivity, such as fatigue and the probable physical pain due to exhaustive exercises or overall loss of energy.

This was especially noticeable with Ligia. Afraid of losing control over her oral needs and of seeing herself at the mercy of bulimic compulsions, she would run several kilometers everyday at the local park, to the point of often injuring her feet. arly in her analysis I made a comment about this and, looking down at her feet, she seemed surprised to see the bruises and said she hadn't noticed them. This type of denial of pain in these patients seems to be directly related to the problem of perception of their own bodies, where the bodily image is distorted in varying degrees. In fact, the lack of any expression of pain is very noticeable in young anorexic women. The anorexic body seems not to feel pain, even when it is deprived of food or when it engages in exhausting physical exercise. It is as if this body existed only in the negative.

In my clinical practice I could not fail to note the association between the onset of a serious or incapacitating physical illness or even an accident, like the one Renata suffered, on the one hand, and intensified concern with the body, on the other. Renata told me that she did not remember being so concerned with her 
body before her accident, but that, since then, she would even avoid going out at night with her friends because she felt "fat." Once again, there is a point in time involved. In her case there was a time before the accident and a time after the accident.

Renata's ability to observe herself led her to spontaneously note that these concerns were "exaggerated and stupid." But the fact that she "felt " this way did not keep her from "feeling" the same thing when she looked at herself in the mirror. Here we can see that a difference between thinking and feeling has been posited. Renata may think critically about her exaggerated concern with her body, but this does not change anything about what she feels in this regard toward her own body or its shape and dimensions. Renata is neither anorexic nor bulimic, but she relates to her body in a way that is very similar to that of young women who do have one or another of these pathologies.

My position is that, in melancholia, through narcissistic identification, the lost object is fused with the ego in both anorexia and bulimia. This lost object seems to be fused with the body, similar to what happens in hypochondria. The extreme attention with which hypochondriac patients listen to their organs and the functioning of their bodies can also be seen in our young anorexic and bulimic patients as they carefully and attentively observe the contours and outside surfaces of their bodies. The concern with the bodily image, strictly appraised in the gaze of others, authorizes me to speak here of a true hypochondria of the image. (In fact, this is strongly present in contemporary culture, although with less exclusiveness). ${ }^{2}$

In cases where anorexia appears related to bulimia, vomiting, and the use of laxatives, as in Ligia's case, the role played by the maintenance of the sense of hunger is even more obvious. This should lead us to the question of the auto-erotic function of hunger and of great motor activity, and their connection with autism, for example. A question comes up here: Does the impulsive motor activity of these patients and their bulimic compulsions and vomiting all constitute auto-erotic behavior? In other words, are such activities desperate attempts at finding a place for auto-eroticism?

The answer to this question is undoubtedly complex, but the fact that we have raised it necessarily takes us, according to Fédida (1990), to the place of

2. With respect to the primacy of the body in contemporary culture, I suggest the following books for interested readers: Mal-estar na atualidade: a psicanálise e as novas formas de subjetivação, by Joel Birman (Civilização Brasileira, 2001) and $O$ vestígio e a aura: corpo e consumismo na moral do espetáculo, by Jurandir Freire Costa (Garamond, 2004). 
otherness in the "autos" of auto-eroticism, or maybe more accurately stated, to the failure to constitute such a place. For Fedida, anorexias and bulimias could be better understood if they could be considered clinically on the basis of the model of autism, which brings onto the scene the importance of the notion of auto-eroticism. ${ }^{3}$

I have taken a topical point of view to construct a metapsychological understanding of these phenomena, giving special emphasis to the relationship between the ego and the body. From the economic perspective, I see the difficulties of the earliest dimension of libidinal economics as especially important, particularly the conditions for the installation of auto-eroticism. From the dynamic point of view, I stress the difficulties of early mother-baby relationships. This emphasis is based on the fact that, by listening to and interpreting her baby's bodily feelings, the mother's investment constructs for the baby the image of its body and, thus, its identity.

\section{The Refused Body in Anorexia and the Foreign Body in Bulimia}

My hypothesis is that in treating subjects with anorexia, there seems to be a phenomenon of anesthesia of the libidinal body. In contrast, bulimia seems to be closer to a negative auto-eroticism, due to the constant search for meaning in the bulimic act and the displeasure frequently experienced.

But even if, in bulimia, pleasure frequently comes in the trappings of pain, there is indeed libidinal investment that assures the experience of the body. It is a body in pain, a misshapen body, one that is hated and forever being watched over so as not to succumb to bulimic temptations, but it is nonetheless a body. It is strange and bothersome, and makes noises. With the libidinal anesthesia of anorexic patients, especially those with the restrictive type, we seem to be dealing with a non-body, a body that has been refused in its erotic aspects, its needs, its materiality, its image. It is the negative of a body, one that cannot be constituted as a mental object. It does not come to the point of constituting the patient's own body.

The refusal of the body in anorexia, through the refusal of hunger, accompanied by extreme weight loss, fatigue and pain, indicates the impossibility of constituting a hypochondriac experience. The perception of pain, for example,

3. See Pierre Fédida's article (1990) Auto-érotisme et autisme. Conditions d'efficacité d'un paradigme en psychopathologie (Revue Internationale de Psychopathologie, n. 2, p. 395-414). 
could contribute to the construction of the structuring function of the body image in subjectivity. ${ }^{4}$ My hypothesis thus sustains the idea that, in patients who show a marked difficulty in perceiving their body, to the point of showing serious distortions in their body images, the experience of the body seems to have remained anchored in the register of need, that is, in a time prior to autoeroticism. It was the constitution of auto-eroticism that was impaired. ${ }^{5}$

A baby's absolute incapacity to assure its own need to survive inevitably joins satisfaction with the image of the caring object. We must therefore try to understand what the basic dependence on the other means for the economy of the subject's libido. Such dependence underlines the importance of the function of feeding in the exercise of the maternal function and, consequently, in the constitution of this erogenous body, whose functioning is the result of the earliest interactions between mother and baby.

In 1920 Freud defined the trauma as the consequence of a disproportion between the intensity of the drives and the ability of the mental apparatus to work through its experiences. Later, in 1926, he wrote that the mother's absence constitutes a traumatic situation. It can therefore be shown that, without a protective function exercised by the mother, the mental apparatus is at the mercy of the drives. Analytic clinical practice often shows that cases of anorexia and bulimia, besides feeding the network of representations that serve as support for the castration anxiety, are also related to the silent character of the death drive. They thus have to do with the more or less durable and harmful effects of the defusing of the drives.

But the idea of defusing the drives implies that there was an earlier time when the drives were fused together. Only what is united can be separated. If we speak of defusing the drives, this implies that we should verify the conditions that had

4. I was also able to note this difficulty in perceiving the body in organically ill patients, a phenomenon that I called the «silence of the organs.» This phenomenon took on metapsychological intelligibility on the basis of comparisons with hypocondria, which allowed me to discuss the problems involved in libidinal development. Interested readers may wish to look at my articles: A hipocondria do sonho e o silêncio dos órgãos: o corpo na clínica psicanalítica, published in the collection Hipocondria (Escuta, 2002); As formas corporais do sofrimento: a imagem da hipocondria na clínica psicanalítica contemporânea, published in the book Psicossoma III (Casa do Psicólogo, 2003) or, in greater detail, to my book L hypocondrie $d u$ rêve et le silence des organes: une clinique psychanalytique du somatique (Presses Universitaires du Septentrion, 1999).

5. See Chap. 4 (A função alimentar: entre o corpo, o eu e o outro) of my book Transtornos Alimentares: anorexia e bulimia (Casa do Psicólogo, 2006). 


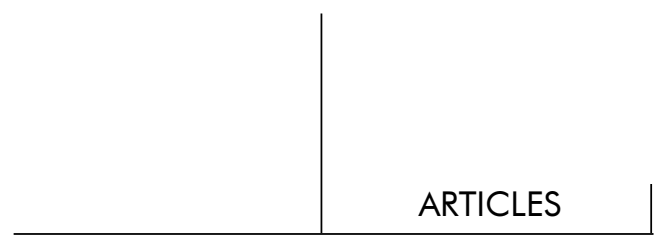

to be in place for the drives to be fused in the first place. And we should investigate everything that might interfere or thwart this process of fusing the drives, which was necessary in order to maintain life. If the mother is to play a central role in managing the drives, this means that we should seek to understand the difficulties that can come to block the operation of the mother's "protective shield" function.

We know that the mother's absence has a traumatic effect on a baby, since the absence represents the disappearance of the baby's protective shield, which protects it from itself. The shield also protects the baby from the feelings that come from inside its own body. Since this absence of protection is traumatic, it can trigger off a compulsion to repeat as a final attempt to fuse the drives together. This failure to connect the drives of Eros and of death creates the conditions for the emergence, among other phenomena, of the effects of masochism in its various dimensions.

The path taken up to this point in the article now enables me to broaden my hypotheses. In the absence of any possibility of feeling what is happening at the level of the patient's own body, as we saw, the onset of anorexia in adolescence brings us face-to-face with a type of discharge that can be understood as an outcome of defusion, or dismantling, of the drives. In the case of bulimia, even if pleasure may come disguised as pain, as we indicated above, it nevertheless indicates the presence of a minimal libidinal investment. It seems that we are not dealing here with a body in the negative, as we sometimes are in the case of anorexia, but with a foreign body. The split between the ego and the body seems to show this impression of strangeness of bulimic patients toward their own body.

In bulimia we are not dealing exactly with a body that has been rejected in its materiality, as occurs in anorexia, but with a foreign hyper-present and exigent body whose demands are frightening because they lack any connection with the subject's ego. The feeling of strangeness that these young women feel can be better understood through the savagery of their bulimic acts. This leads us to note the frightened gluttony of a body that seems not to belong to them. If bulimic acts subordinate the body to such excesses and even to pain, might we not be seeing here a desperate attempt to create a refusioning of the drives, seeking to reactivate the connective functions of the original masochism? Given it's the masochism that implies an enduring a connection with the object to which such suffering might be addressed, might we therefore consider that in anorexia, the problem predates the original masochism?

As Freud pointed out, auto-eroticism is merely a response to the loss of the object that guaranteed satisfaction. This, of course, implies that, if auto-eroticism does not come about, the baby will be unable to deal with the absence of the 
object. In other words, the absence will be hard to bear if it cannot be appeased through auto-erotic satisfaction. One can posit that it is under these conditions that the absence of the object takes on its full dimension by preventing or at least hampering what is needed in order to fuse the drives. In metapsychological terms, I suggest that bulimia and, especially, anorexia have made evident how precarious the drive fusion is very early in life. In my view this precariousness may have been installed due to difficulties or discontinuities in the exercise of the mother's "protective shield" function.

Thanks to this protective function, the child acquires an awareness of its body, its feelings, its needs and its affects. By exercising this function the mother organizes the child's contact not only with its love and hate, and its capacity to love, destroy or bind with the other, or to become isolated from it. This contact also serves to foster pleasure and bear suffering. The mother's "protective shield" function, then, has a triple purpose. It is not merely to protect and to mediate. It also has a libidinizing function, and it can thus be affirmed that the libidinizing dimension of the mother's "protective shield" function represents a condition for there to be a fusion of the drives.

The mother's "protective shield" function can be partially replaced only by introjecting it, and it is this introjection that will guarantee the constitution of an internal object, which, in the mother's absence at later moments, will enable the baby to face the excesses and adversities inherent to growth and to the acquisition of autonomy. If, due to some difficulty, the object fails in this function, the mechanism of introjection cannot operate. Strictly speaking, we can say that the introjection of the drives and their vicissitudes supposes a previous introjection, not of the object, but of the mother's "protective shield" function.

\section{A Triple Refusal}

This understanding now enables us to add a further important point to my hypotheses. If the mother's "protective shield" function was not introjected, the subject becomes lost in the excesses of the drives. My hypotheses include the idea that in both anorexia and bulimia the processes proper to adolescence eventually cause a drive defusion precisely because the processes encounter a drive fusion that is precarious, and only partial. These processes are the result of difficulties in introjecting the mother's "protective shield" function, especially in its libidinizing aspect. In other words, the processes proper to adolescence bring about a drive defusion when they encounter a fusion that has been made precarious, 
especially by the difficulties in introjecting the mother's libidinizing function.

It can thus be supposed that in anorexia, and especially in restrictive anorexia, the process of drive fusion was even more precarious than that which occurs in cases of bulimia. It is as if the drives had been only partially fused. As was mentioned above, on the basis of this reasoning it makes sense to consider that, in anorexia, we are at a point prior to original masochism.

We have seen that bulimia represents an attempt at drive refusioning by seeking to reactivate the functions of connection first carried by the original masochism, in the suffering inflicted on the body through eating excesses, vomiting and even physical exercises. For this reason, anorexia, even the restrictive type, also represents an attempted drive refusioning. But very early in life this attempt comes up against even more precarious drive-fusion processes.

As numerous analysts have pointed out, we are dealing in both anorexia and bulimia with a failure to introject the drives. This becomes evident in adolescence, where such failure is due precisely to some incapacity to establish introjection. Therefore, in view of the failure to introject the mother's "protective shield" function, the subject, helpless before the emergence of the drives, must resort to incorporating the object. We can thus consider that, in anorexic and bulimic young women, primary identification becomes deadlocked in incorporation, which is its bodily prototype. On the other hand, however, introjection would enable the subject to reduce its dependence on the object. The incorporation of the object creates and reinforces imaginary object connections. This allows us to advance in our understanding of the difficulties in distinguishing subject from object, so frequently seen by psychoanalysts in their clinical work with anorexic and bulimic patients. ${ }^{6}$

My hypotheses make it clear that the mother, through her protective shield function, generates an erogenous body and points along the road toward symbolization. So it is she who, since times before auto-eroticism, has carried out the task of symbolizing for the baby. Without this period of time, the psychic apparatus remains exposed to the precocity of the trauma. Without symbolization there is no possibility of repression. What emerges instead is a compulsion to repeat and the mechanisms of refusal and splitting. The mechanism of splitting (Spaltung) returns late in Freud's work, especially after his article on Fetishism (1927), when the notion of refusal (Verleugnung) takes on greater weight. ${ }^{7}$

6. See Chap. 5 (A função alimentar: além do princípio do prazer) of my book Transtornos Alimentares: anorexia e bulimia (Casa do Psicólogo, 2006).

7. In regard to splitting, I refer the reader to Freud's texts: Fetichismo (1927), A divisão do ego no processo de defesa (1938) and Esboço de Psicanálise (1940). 
For Kestemberg, Kestemberg and Decobert (1972), ${ }^{8}$ hunger becomes eroticized in anorexia. For me, these cases of anorexia seem to represent attempts at drive refusioning by eroticizing the control over bodily needs as a whole and not only over hunger. For while in bulimia the body is a foreign body, in anorexia, the body has been refused in its materiality and its needs. The eroticization of control denies the anorexic's body its humanity, creating impasses which only increase the gravity of these cases and the difficulties in handling them in the clinic.

It should be noted that the refusal here is not exactly a refusal of exterior reality, as we usually see in psychosis, but a refusal of the reality of the patient's own body. It is obvious, then, that a refusal of the reality of the body, in what it has of mortal and erotic, not only plays an important role in anorexia and bulimia. It also lets us establish a border with psychosis.

The refusal of human reality, in what it has of mortal and erotic, suggests that anorexia implies the presence of a fantasy of the indestructibility of the body, as if the subject were refusing to see herself as vulnerable. The feeling of omnipotence and the refusal of the reality of one's own body seem to be closely related. This combination fits in well with a very powerful ideal ego that leads the subject to try to hold onto firmly to the illusion of a body that is impermeable to both death and time. Might this fusion with the ideal also indicate attempts to refuse otherness and its effects on the subject's destiny?

In my opinion the refusal of the reality of one's own body seen in these young people in fact encompasses a triple refusal: of death, of time and of the other. If such subjects were led to make such obstinate refusals, this may be an indication of the intensity of the danger they faced when setting up these powerful defenses.

As we saw above, failures in the mother's investment and the precariousness of the protective shield introjected by the baby make it difficult to construct a bodily image that will include the perception, representation and feeling of the subject's own body. But excessive maternal investment also disturbs these experiences. An intrusive mother is as harmful as an absent one, and this can be seen in the negative effects of what I have characterized as a mother of extremes. The intensity of the danger that demands such impenetrable defenses would seem to be directly related to the difficulty in differentiating the maternal figure that eloquently calls for a refusal of the passage of time, of the vulnerability inherent to human existence, and of the need for the object. ${ }^{9}$

8. See the book La faim et le corps by E. Kestemberg, J. Kestemberg and S. Decobert (PUF, 1972).

9. See Chap. 6 ("Um corpo para dois") of my book Transtornos Alimentares: anorexia e bulimia (Casa do Psicólogo, 2006). 


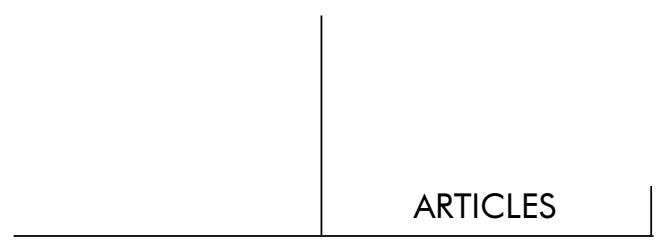

Everyday Life in the Clinic

The difficulty in perceiving physical feelings is accompanied in these young women by another, equally important difficulty, namely, to perceive their interior world and their emotional needs. What stands out is that, even though there are apparently complex phantasmic activities involved, these do not seem to favor any process of enrichment of imagination and relationships. The fantasies seem to be imprisoned in the emerging body, often in a concrete, anti-metaphorical way. Our young women seem have been deprived of their internal space, dispossessed of an interior life. According to Bidaud (1998), this dispossession of space refers to the body, to the affects and to thinking. ${ }^{10}$

The analyst's sensitivity and careful handling will guide him or her through the dryness of these hard-to-reach places that are unaccustomed to contact with others. The analyst must be sparing as he or she doses out interpretations. It is exactly when the transferential experience begins to move out of its initial frozen situation that the bond between the two may become potentially destructive and threatening.

The main difficulty in conducting the analytic process of these young patients is in finding the right dose, or the right balance, between proximity and distance, between silence and speaking. The paradox resides precisely in the fact that interest in the analytic work and the pleasure in the contact with the analyst can also simultaneously become a source of anxiety, probably because they bring to the fore the threat of differentiation and fusion that the patient experienced with their mother. The omnipotent control over the body repeats, in the transference, the relationship experienced with the mother. It is a relationship marked by absence and intrusion, helplessness and despair, and all this demands sensitivity and patience from the analyst. Nothing should be hurried along!

The paradoxical dimensions of this transference, oscillating between fascination and terror, love and hatred, life and death, mean that the analyst must be able to exercise the "protective shield" function in its triple dimension of protection, mediation and libidinization. This allows the analytic situation to function as a reorganizer in libidinizing the body. Only under these conditions can phantasmic activity re-emerge in all its virtuality and diversity.

It is along this tenuous fine line of opposing forces that the space and time of the sessions will gradually be occupied by attempts to name what is being

10. See the book Anorexia Mental, ascese, mística: uma abordagem psicanalítica, by Eric Bidaud (Companhia de Freud, 1998).

Rev. Latinoam. Psicopat. Fund., São Paulo, v. 15, n. 3, p. 668-682, setembro 2012 (Suppl.) 
experienced between analyst and analysand. It is almost like an effort to "think out loud," to "give voice," about what is being experienced. It first acts through feelings in the body, which open the path to thoughts that can then flow through, fed by affects, nighttime dreams and daydreams. It is a slow and delicate process, and the analyst must often go into detail about subjective experiences, patiently accustoming these young people to explain to us what they want to say and what they are feeling. Talking about oneself is also essentially a way of listening to oneself. Therefore, analytic work should be able to lead these patients to listen to themselves.

The analytic situation functions here by letting the analysand bring back bits of memory, join pieces together, create meanings and invent forms, thus freeing their phantasmic activity from its defensive modalities which gave such a privileged place to experiences and feelings in the body. Treating these young women opens up the unavoidable road to physical sensation, described and invested at the beginning as material that we analysts must become used to listening to without prejudice. It is this voyage through the body of the anorexic, at a slow and delicate pace, that will permit a transition from this refused body to a body that is invested, or libidinized, by the analyst's presence and word.

These young women are asking us for the ability to live with their emptiness and incompleteness, to patiently move between vulnerability and tenderness, They want from us the willingness to creatively construct fictional theories which, feeding our capacity to keep on thinking, will help us resist having to cross the desert. With them we must face the need to manage the anxieties of intrusion, destruction, collapse and emptiness. There is also need, of course, to guarantee the development of a protective shield function that mediates and libidinized and, at the same time, takes into account both the body and the word in the management of the transferential relationship.

Everything takes place so that the analyst's word will encourage these patients to develop their ability to imagine in such a way that the experiences which affect the body, the emotions and thinking take on metaphoric possibilities. As Fedida wrote (1977), "The metaphor is a dwelling place and the psychoanalyst needs the poem in order to inhabit the metaphor" (p. 131). ${ }^{11}$ The analyst should therefore seek inspiration from the figure of the poet. In this way he will safeguard his ability to daydream with words and create images based on silence, and thus become able to discreetly and serenely occupy the void. As René Chair said, "A poet must leave traces of his passage, not proof. Only traces make us dream." 
Abstracts

(O corpo na anorexia e na bulimia)

A clínica psicanalítica da anorexia e da bulimia nos confronta de saída com a questão do corpo, assim como nos coloca diante da especificidade dos processos da adolescência. Tal especificidade evoca as vicissitudes da relação precoce com a mãe no que diz respeito ao gerenciamento pulsional e sua relação com a identificação primária e, consequentemente com os ideais, a diferenciação, a autonomia, o tempo e a morte. Este texto traz para a discussão algumas hipóteses, elaboradas a partir da metapsicologia, com o objetivo de contribuir para uma melhor compreensão do processo de construção da imagem corporal, que inclui a percepção, a representação e a experiência interna do corpo próprio. Os impasses vividos na situação analítica assinalam, ainda, as particularidades no manejo transferencial desses casos.

Palavras-chave: Anorexia/bulimia, imagem corporal, metapsicologia, manejo transferencial

(Le corps dans l'anorexie et dans la boulimie)

La clinique psychanalytique de l'anorexie et de la boulimie nous confronte avant tout à la question du corps, ainsi qu'à la spécificité des processus qui ont lieu pendant l'adolescence. Une telle spécificité évoque les avatars de la relation précoce mère-bébé en ce qui concerne le maniement pulsionnel et son rapport avec les identifications et, par conséquent, avec les idéaux, la différenciation, l'autonomie, le temps et la mort. Cet article discute quelques hypothèses métapsychologiques concernant la compréhension du processus de construction de l'image corporelle, qui inclut la perception, la représentation et l'expérience subjective du corps propre. Les impasses vécues dans la situation analytique soulignent d'ailleurs les particularités dans le maniement transférentiel de ces cas cliniques.

Mots clés: Anorexie/boulimie, image corporelle, métapsychologie, maniement transférentiel

(El cuerpo en la anorexia y en la bulimia)

La diversidad psicopatológica encontrada en la clínica psicoanalítica de la anorexia y de la bulimia nos confronta inicialmente con la cuestión del cuerpo, así como nos pone frente a la especificidad de los procesos de la adolescencia. Tal especificidad evoca las vicisitudes de la relación precoz con la madre en lo que atañe al manejo pulsional y su relación con la identificación primaria y, por consiguiente, con los ideales, la diferenciación, la autonomía, el tiempo y la muerte. Este texto trae a la discusión algunas hipótesis elaboradas a partir de la metapsicología, con el objetivo de contribuir para una mejor comprensión del proceso de construcción de la imagen corporal, que incluye la percepción, la representación y la experiencia interna del propio cuerpo. Los impases vividos en la situación analítica señalan, además, las particularidades en el manejo transferencial de esos casos.

Palabras clave: Anorexia/bulimia, imagen corporal, metapsicología, manejo transferencial

Rev. Latinoam. Psicopat. Fund., São Paulo, v. 15, n. 3, p. 668-682, setembro 2012 (Suppl.) 
(Der Körper bei Anorexie und Bulimie)

Die klinische psychotherapeutische Behandlung von Anorexie und Bulimie stellt uns umgehend gegenüber der Frage zum Körper, so wie der Spezifik der Prozesse in der Pubertät. Diese Spezifik weist auf die Schicksale der frühen Beziehung zur Mutter bezüglich der Beherrschung der Triebe und ihres Bezugs zur primären Identifizierung und folglich zu den Idealen, der Absonderung, der Autonomie, der Zeit und dem Tod. Dieser Text stellt einige von der Metapsychologie ausgehend aufgestellten Hypothesen zur Diskussion, mit dem Ziel, zu einem besseren Verständnis des Entwicklungsprozesses der Körperauffassung beizutragen, was die Wahrnehmung, Vorstellung und interne Erfahrung des eigenen Körpers mit einbezieht. Die in einer analytischen Situation erlebten Engpässe zeigen außerdem die Besonderheiten der übertragenden Behandlung dieser Fälle.

Schlüsselwörter: Anorexie/Bulimie, Körperauffassung, Metapsychologie, Übertragungsvorgang

Citation/Citação: Fernandes, M.H. The Body in Anorexia and Bulimia . Revista Latinoamericana de Psicopatologia Fundamental, São Paulo, v. 15, n. 3, p. 668-682, sept.2012 (Suppl.).

Editor/Editor do artigo: Prof. Dr. Manoel Tosta Berlinck

Received/Recebido: 4.7.2012 / 7.4.2012 Accepted/Aceito: 25.8.2012 / 8.25.2012

Copyright: (C) 2009 University Association for Research in Fundamental Psychopathology / Associação Universitária de Pesquisa em Psicopatologia Fundamental. This is an open-access article, which permits unrestricted use, distribution, and reproduction in any medium, provided the original author and source are credited. / Este é um artigo de livre acesso, que permite uso irrestrito, distribuição e reprodução em qualquer meio, desde que o autor e a fonte sejam citados.

Funding/Financiamento: The authors have no support or funding to report. / Os autores declaram não ter sido financiados ou apoiados.

Conflict of interest/Conflito de interesses: The authors declare that has no conflict of interest. / Os autores declaram que não há conflito de interesses.

\section{Maria Helena Fernandes}

Psychoanalyst, Doctor in Psychoanalysis and Psychopathology from University of Paris VII, with post-doctoral work at the Department of Psychiatry of Unifesp, in São Paulo, SP. Br.; Professor in the Course in Psychosomatics at Sedes Sapientiae Institute, São Paulo, SP. Br. and author of the books L'hypocondrie du revê et le silence des organes: une clinique psychanalytique du somatique (Villeneuve d'Ascq: Presses Universitaires du Septentrion, 1999), Corpo (“Clínica Psicanalítica" Collection, São Paulo: Casa do Psicólogo, 2003) and Transtornos Alimentares: anorexia e bulimia (Casa do Psicólogo, 2006).

Rua Dr. Diogo de Faria, 1087/905 - Ibirapuera

04037-030 São Paulo, SP, Br

e-mail: fernandes.mh@terra.com.br

Rev. Latinoam. Psicopat. Fund., São Paulo, v. 15, n. 3, p. 668-682, setembro 2012 (Suppl.) 